\title{
Research on innovation of Rural grassroots Governance driven by New Township talents from the perspective of "Internet +
}

\author{
Meng Zhang ${ }^{1}$ \\ ${ }^{1}$ Guangzhou Nanyang Polytechnic College, Guangzhou 510925, China
}

\begin{abstract}
Internet + " is a further practical result of Internet thinking, which promotes the continuous evolution of economic forms, thus driving the vitality of social and economic entities and providing a broad network platform for reform, innovation and development. At the same time, the role of the new townsfolk in the construction of the new countryside includes the governance of the rural grass-roots level, which gradually attracts extensive attention from all walks of life. Aims to explore the prevention and get rid of rural grassroots governance crisis, the sustainable way to maintain close ties with the masses, for the revitalization of the construction of rural areas, to guide the new follow villager boost rural grass-roots governance, because new follow villager unique localism and moral superiority, this system research problem related to new follow villager and rural grassroots governance is needed urgently. Social governance at the rural grass-roots level is the social foundation for rural revitalization. Without effective social governance at the grass-roots level, the strategy of rural revitalization will not be fully realized."Internet + Governance" is the only way to realize the modernization of grassroots governance. It is also a stepping stone for grassroots governments to use technological means to closely integrate democratic governance with the well-being of the people. It not only realizes the people-oriented care of people, but also reflects the governing principle of the rule of law.
\end{abstract}

\section{The introduction}

In October 2017, the strategy for rural revitalization was first put forward in the report to the 19th CPC National Congress. Now, the rural revitalization has shifted from the concept to the implementation stage, and the rural grass-roots social governance is the social foundation for the realization of the rural revitalization strategy. With the rapid change of China's macro environment, a series of changes are taking place in the politics, economy, culture, social structure and people's ideas of rural grass-roots society. In the process of promoting the rural revitalization strategy, social governance at the rural grass-roots level has faced new challenges. Under the new situation, how to make rural grass-roots social governance more effective needs further investigation and research.

In early 2018, the State Council issued the Opinions of the CPC Central Committee and the State Council on The Implementation of The Rural Revitalization Strategy, providing comprehensive guidance for the implementation of China's Rural revitalization Strategy.In 2019's No. 1 Document of the CPC Central Committee, it is proposed to "comprehensively promote rural revitalization."It can be seen that rural revitalization has shifted from the conceptual level to the implementation stage. The "prosperous industry, livable ecology, civilized countryside style, effective governance and rich life" that are needed to achieve rural revitalization are reflected in all aspects of rural grass-roots social governance. The improvement of social governance at the rural grass-roots level is the social foundation for rural revitalization. Without effective social governance at the grass-roots level, the rural revitalization strategy cannot be fully realized.

The 19th National Congress of the COMMUNIST Party of China (CPC) stressed the need to "raise people's ideological awareness, moral standards and cultural attainment, and raise the level of civilization of the whole society", which is undoubtedly a new goal and requirement for strengthening grassroots ideological governance. Whether the national quality and social civilization can be significantly improved depends on the moral quality of farmers and the level of rural civilization. Therefore, as an important part of socialist spiritual civilization construction, rural grassroots governance has a long way to go.Therefore, combined with the hot spots of new townsfolk and the difficulties of rural grassroots governance, the multidimensional analysis of the related issues of "research on new townsfolk helping Rural grassroots governance" has corresponding academic value and practical significance. 


\section{Significance of research}

\subsection{Theoretical significance}

Though, since the $19 \mathrm{big}, \mathrm{Xi}$ as the core of the collective leadership, on different occasions put forward the idea of "strengthening the rural grass-roots governance" general requirements, the national party and government organizations at all levels, especially the rural grass-roots party organizations to grasp implementation, improve ideological and moral quality of the peasants, rural harmonious society in a certain extent, also. First of all, the study of rural Revitalization strategy can enrich the content of public management and provide relevant theoretical basis for the study of rural grass-roots social governance under the new situation. Secondly, rural grassroots social governance is a very important part of the construction of national governance system. An in-depth study of social governance in rural communities can supplement and improve the relevant content of national governance theory and promote the modernization of national governance capacity as soon as possible. Thirdly, the management concept of township government as the core of governance has been gradually broken. The theory of joint governance of multiple structures, including village party organizations, township governments, villagers' committees, rural social organizations and farmers, has been gradually established, which has far-reaching implications for exploring new ways of diversified cooperation.

The research of this paper is helpful to the research of rural revitalization strategy and rural grass-roots social governance to some extent.Contributed to the "new follow villager boost rural grassroots governance" issues related to the research content, from a new follow villager power analysis the possibility and necessity of the rural grass-roots governance, The system to interpret the new follow villager to help the concrete embodiment and realistic obstacle of rural grassroots governance, to put forward the solution, can make the new follow villager power rural grassroots governance issues related to the research contents are rich.Secondly, it is helpful to expand the research horizon of new townsfolk and rural grassroots governance, and carry out the research combining the hot spots of new townsfolk and the difficulties of rural grassroots governance.It can enrich the content of the research on the issue of "new townsfolk help rural grass-roots governance", and further expand the research horizon of new townsfolk and rural grass-roots governance.

\subsection{Practical significance}

From the perspective of practice, with the rapid change of the macro environment, the politics, economy, culture, environment and people's ideology of the rural grass-roots society are subtly changing. In the process of promoting the rural revitalization strategy, the rural grass-roots social governance has faced new challenges. The legal environment needs to be optimized, and the legal construction is not complete. The consciousness of moral governance needs to be strengthened, and the construction of moral governance is not perfect.The lack of the main body and the lack of power and other specific problems in rural grass-roots governance make it need to be further improved. Therefore, it is urgent to appeal to the power of all aspects.

By studying first to under the premise of full understanding of the new follow villager groups, in-depth analysis of the role of new follow villager in rural grass-roots governance, policy in reading documents, news reports, scholars in the process of the article, can get a comprehensive understanding of the main body of new follow villager groups, advantage, position, and to analyze its specific functions in the course of rural moral fitness.Secondly, it is conducive to further understanding of the specific problems in rural ethics, so as to put forward solutions to specific problems. Through reading and analyzing relevant literature, we can further understand that lack of subject and lack of motivation are the problems that grassroots governance needs to be solved. Theory and facts have proved that new villagers are indeed the "breakthrough" to solve the existing problems, which provides a new way of thinking for solving the existing problems of rural grassroots governance.

To sum up, both theory and practice have proved that the new villagers, with their unique local feelings and moral advantages, can effectively alleviate the existing problems of lack of subjects and lack of motivation in rural grass-roots governance.Therefore, it is possible and necessary for this topic to study the specific performance, realistic obstacles and path choice of new townsfolk to help rural grass-roots governance.

\section{Research content}

With the progress of society and the development of scientific research. Both at home and abroad attach great importance to the analysis of social governance problems at the rural grass-roots level from the perspective of multiple subjects. Although scholars at home and abroad have been increasingly comprehensive in their research on rural grassroots social governance, China's rural grassroots governance has unique Chinese characteristics, especially after the "rural revitalization strategy" was proposed, the rural grassroots social governance system that ADAPTS to the pace of China's development has not been effectively established and completed at this stage.Under the background of "Internet plus", how to make social governance at the rural grass-roots level more effective requires further development and improvement. 


\subsection{Overall framework of the project}

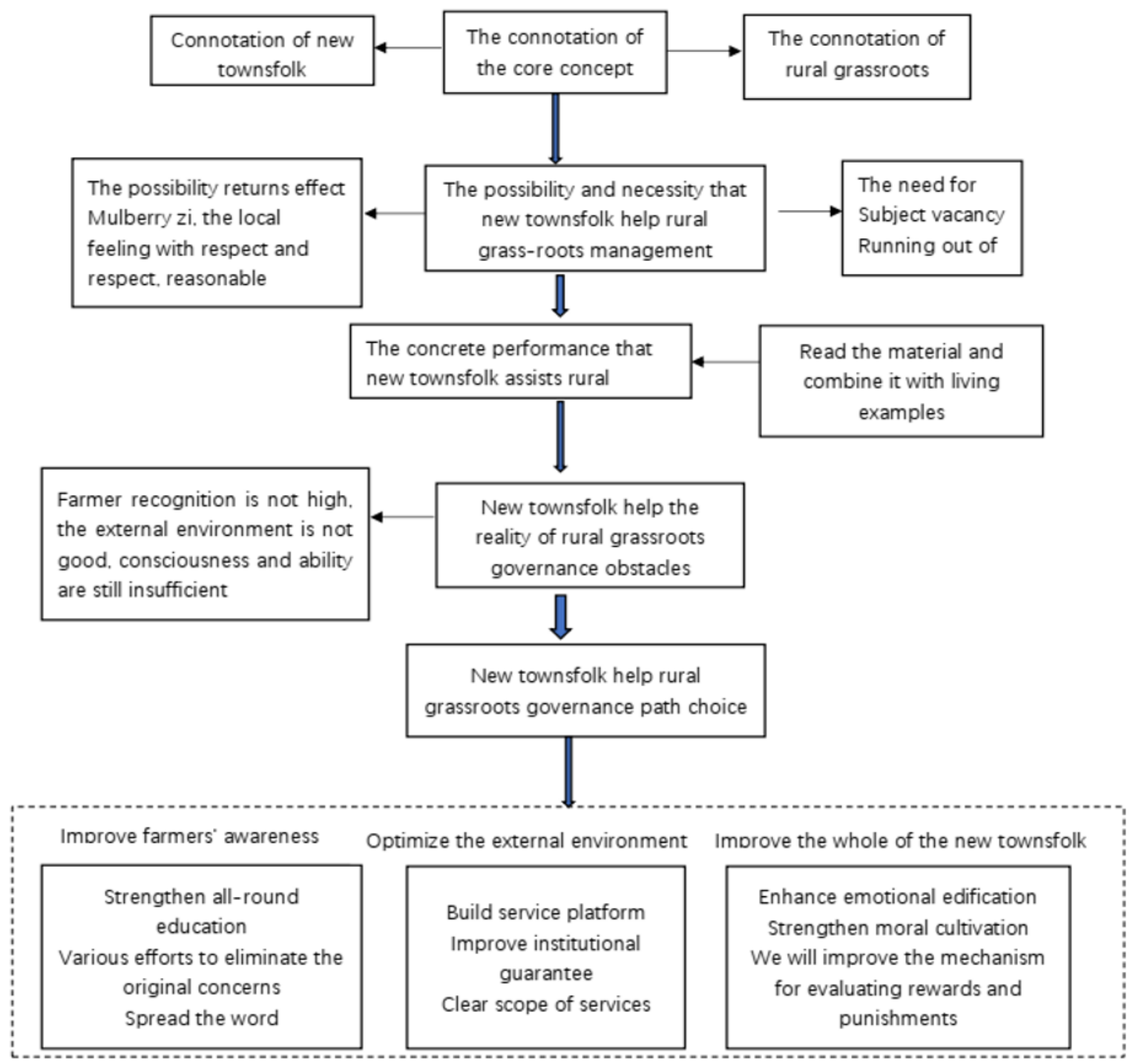

Figure 1 Overall framework of the project

\subsection{Basic contents of the project research}

\section{(1) The connotation of core concepts}

\section{A. Internet +}

The concept of "Internet plus" in China can be traced back to Yu Yang's speech at the 5th Mobile Internet Expo of Analysys in November 2012.Yu Yang, chairman and CEO of Analysys International, first proposed the concept of "Internet plus"."Internet + " is a new form of Internet development under innovation 2.0 and a new form of economic and social development under the impetus of innovation 2.0 in the knowledge society.

"Internet + " is a further practical result of Internet thinking. It promotes the continuous evolution of economic forms, thus driving the vitality of social and economic entities and providing a broad network platform for reform, innovation and development.Generally speaking, "Internet plus" means
"Internet plus various traditional industries". However, it is not simply a combination of the two, but a deep integration of the Internet and traditional industries through information and communication technologies and Internet platforms to create a new development ecology.It represents a new social form, that is, make full use of the Internet in the allocation of social resources optimization and integration, incorporates the depth of the innovation of the Internet in economic and social each domain, improve the creativity and productivity of the whole society, the formation of a wider range of internet-based facility and realize the economic development of tools for new form.

\section{B. Rural revitalization strategy}

In his report to the 19th National Congress of the COMMUNIST Party of China (CPC), General Secretary $\mathrm{Xi}$ Jinping for the first time put forward the "Rural revitalization strategy", and stressed that agriculture, farmers and rural areas are fundamental issues affecting 
the national economy and people's livelihood. We must make solving these issues a priority task and resolutely implement the rural revitalization strategy. We will elevate rural revitalization to the level of a national strategy and, proceeding from the overall situation of national development, implement the important guiding principle of giving priority to the development of agriculture, farmers and rural areas. In March 2018, Premier Li Keqiang kicked off the rural revitalization strategy with the Government Work Report. In September 2018, the CPC Central Committee and the State Council issued the Strategic Plan for Rural Revitalization (2018-2022). Since then, governments at all levels have formulated their own strategic plans for rural revitalization in accordance with local conditions. Governments at all levels have gradually established and improved institutions, mechanisms and political systems for rural development in accordance with the general requirements of "thriving industries, livable ecology, civilized local customs, effective governance and a prosperous life". We will continue to coordinate rural development in all areas and accelerate the modernization of rural governance systems and capacities so as to gradually realize agricultural and rural modernization. We must unswervingly follow the path of rural revitalization chosen by society with Chinese characteristics, and make rural areas beautiful homes for farmers to live and work in peace and contentment.

\section{Connotation of new townsfolk}

Follow villager, "Chinese big dictionary" explanation for the "village man of noble virtue", the historical facts have proven that in traditional society, follow villager had with other traits such as morality, knowledge, wealth, prestige and villagers in enlightenment to sustain the rural social order stability plays an important role, when things change, move easily, wave enveloped in the modernization development, a large number of outstanding talent to the rural areas to the cities "hollow village" with increasing, the construction of new socialist rural areas lack of internal motivation gradually, therefore, clear follow villager era connotation is imperative. The scientific community defines the subject scope of the new townsfolk is the first way to define the new connotation of the new era. Held in September 2014 the cultivation and practice of socialist core values of exchange conference of work experience, then the central propaganda department minister Liu Jibao pointed out that "rural grassroots cadres, excellent moral models, good man around, such as advanced deeds, grew up in rural, the dedication to village, the villagers neighborhood high prestige and good reputation, is the main part of the 'new follow villager."This exposition can be said to be the central authority to define the subject scope of new townsfolk.

At the same time, as the new townsfolk are the modern reflection and inheritance innovation of the traditional townsfolk spirit, the scientific definition of the subject scope of the new townsfolk should also be made clear where the "new" is compared with the traditional townsfolk. Having extensive moral influence is the common point between new and traditional townsfolk, which is more called the basic basis of townsfolk. However, the differences between them are reflected in personnel structure, historical background, way of thinking, status and function, etc., and these differences are exactly the "new" of new townsfolk.

In addition, the classification of new townsfolk is also crucial to fully explain the connotation of new townsfolk. Zhang Yiwu classifies new townsfolk into two categories "present" and "absent". To be specific, the former refers to the rural elites who come from, take root in and serve the local areas and are welcomed by peasants for their morality, reputation, knowledge and other characteristics, such as outstanding grass-roots cadres in rural areas, retired cadres, moral models and good people around them. The latter refers to the elites from all walks of life who have left their native land for reasons such as studying, becoming an official or doing business. Although they have not lived in the countryside for a long time, they still love their native land and contribute their strength to it through various ways, such as entrepreneurs who have come out of the countryside, educational researchers and cadres of government organs.

In conclusion, in the scientific community to define the subject scope, clear where the "new", make a classification on the basis of the basic connotation of the new follow villager nature to do the following definition: in today's society, was born in rural, love the countryside, a word of mouth, high prestige, and to use scientific way of thinking active service in the rural social economic development, and puts it can do all aspects of rural development has great benefits.

\section{Rural social governance at the grassroots level}

In this paper, social governance at the rural grass-roots level refers to the activities of jointly solving social problems at the rural grass-roots level within the governance scope of towns and villages, taking the rural society and rural residents as the object, utilizing governance mechanism and exerting multiple main forces. In mid-June 2015, General Secretary Xi Jinping mentioned in his research in Guizhou that "the most solid strength of the Party's work lies at the grass-roots level, and the most prominent contradictions and problems in economic and social development and people's livelihood also lie at the grass-roots level". In the report to the 19th National Congress of the Communist Party of China (CPC) held in October 2017, it said: "We will strengthen basic work in rural areas and improve the rural governance system that combines self-governance, rule of law and rule of virtue."These have illuminated the front and guided the direction of social governance at the rural grass-roots level in China. In the context of the implementation of the rural revitalization strategy, it is necessary to promote the coordination and cooperation of multiple entities so as to better adapt the rural grass-roots social governance to the development of the new era.

It is an inevitable trend of social development that the subjects of social governance at the rural grass-roots level are diversified and complicated. Nowadays, social affairs and conflicts and disputes at the rural grass-roots level are increasingly diversified and complicated. It is 
necessary for multiple subjects to complement each other, cooperate with each other, and comprehensively apply diversified governance means to meet the needs of rural development. The body of the rural grass-roots social governance in addition to the rural grass-roots party organizations and the villages and towns government, also need to include: rural grassroots self-governing organizations, rural grass-roots social organizations and peasants, the attack of plural integration management power, they can better promote the realization of the rural grass-roots social good governance, to promote rural revitalization strategy implementation.

(2) The relationship between rural revitalization strategy and social governance at the rural grass-roots level

Rural revitalization Strategy Rural grass-roots social governance is inextricably linked, closely linked, inseparable. On the one hand, the implementation of the rural revitalization strategy puts forward objective requirements for improving the social governance at the rural grass-roots level. To implement the strategy of rural revitalization, it is necessary to coordinate and promote the all-round development of the economy, politics, culture, society, ecological construction and party organization construction in rural communities. Therefore, to realize the strategy of rural revitalization, it is an inevitable choice to establish and improve the social governance system at the rural grass-roots level and realize "good governance" in rural areas. On the other hand, the realization of "good governance" in rural grass-roots social governance can better promote the comprehensive realization of rural revitalization strategy. With the progress of The Times, all kinds of new disputes and contradictions come to the rural grass-roots society. It is necessary to gradually improve the way of social governance at the rural grass-roots level, solve the practical problems of social governance at the rural grass-roots level, gradually improve the system of social governance at the rural grass-roots level, make a good front for the handling of public affairs at the rural grass-roots level and carry out all kinds of work, so as to promote the comprehensive realization of the rural revitalization strategy.

(3) The role of new villagers in rural grassroots governance from the perspective of "Internet plus"

By reading the related materials and combined with living examples, can be concluded that the new follow villager in participating in the rural grass-roots governance provides the main force, integrated into the power and close to farmers to support and drive the rural economic and social development to provide material base, the process of dissemination of the mainstream values to provide value guidance, can effectively help rural grass-roots governance. Through the analysis of the specific performance of new townsfolk to help rural grass-roots governance, it is not only the requirement to expound the possibility and necessity of new townsfolk to help rural grass-roots governance, but also the key to study the related issues of new townsfolk to help rural grass-roots governance.
New villagers can and should help rural grassroots governance.In the scientific definition of appropriate new follow villager and connotation in the process of rural grassroots governance, It is not difficult to find that the new townsfolk have the unique characteristics to help the rural grass-roots governance, and the existing problems of rural grass-roots governance is in urgent need of the new townsfolk to intervene and play the role of application, that is, there is no doubt that it is possible and necessary for the new townsfolk to help the rural grass-roots governance. To be specific, the possibility of new townsfolk helping rural grassroots governance lies in their local feelings and moral advantages of serving the motherland, being highly respected, sympathizing with and reasoning. However, the lack of subjects and lack of power in the current rural grassroots governance is the necessity of new townsfolk helping rural grassroots governance.

(4) Problems and feasible approaches of new villagers in rural grass-roots governance from the perspective of "Internet + "

With the unique localism and moral superiority, new follow villager by participating in the rural grass-roots governance, blend in and near to farmers, drive the rural economic and social development and dissemination of the mainstream values for the rural grass-roots governance main body force, power support, material basis and value guidance, it helps the manifestation of rural grassroots governance is to have eyes and see, for sure.However, at the same time, it should also be admitted that, under the influence of subjective and objective factors, new townsfolk are still in the primary stage to help rural grass-roots governance. In reality, they inevitably encounter multiple obstacles such as low recognition of farmers, poor external environment, and insufficient awareness and ability.

New follow villager power of rural grassroots governance path selection to give full play to the advantages of the new follow villager in rural grassroots governance, also in response to the current subject vacancy of rural grassroots governance and underpowered, and find out the solution to existing problems, new follow villager power of rural grassroots governance is to analyze the related problems of the foothold and home.To this end, corresponding to the three levels of farmers' recognition, external environment and the obstacles of the new township elites themselves, this paper proposes the path choice of the new township elites to help the rural grass-roots governance.Optimize external environment by building service platform, perfecting system guarantee and clarifying service scope; By increasing the emotional edification, strengthening the moral cultivation and perfecting the evaluation mechanism of reward and punishment, the overall quality of new townsfolk can be further improved. 


\section{Research methods and technical routes}

\subsection{Research methods}

\section{A. Literature analysis}

By means of the existing literature research, search and read the new follow villager power of rural grassroots governance related information, rural revitalization strategy related policy report, using the dialectical objective view to the trade-off, thinking, analyzing the new follow villager power and the research status of rural grassroots governance and research level, form the new follow villager help scientific understanding of rural grassroots governance.Literature review was conducted by using CnKI and the school library to collect domestic and foreign researches on social governance at the rural grass-roots level, and the collected literature on social governance at the rural grass-roots level was sorted out, summarized and summarized.

\section{B. Questionnaire survey method}

Y style town in Conghua District, Guangzhou has 26 administrative villages with a population of more than 50,000 , with an average of 2,000 people in each village. On average, 20 villagers are randomly selected from each village to issue questionnaires.Know them to guangzhou conghua district town rural grass-roots social governance $\mathrm{Y}$ feelings and ginseng township, induction, summary they think the country revitalization under the background of guangzhou conghua district $\mathrm{Y}$ town in rural grassroots social governance problems that exist in the process, combination with $\mathrm{Y}$ town in guangzhou conghua area scale, to guangzhou conghua district $\mathrm{Y}$ town rural grass-roots social governance condition investigation, draw a relatively comprehensive and objective data.

\section{Case interview method}

First of all, from the guangzhou conghua district town ZuZhiYuan Y office, agricultural economy management station, the office of spiritual civilization, comprehensive management office and HuanBaoSuo randomly selected from each department of the five departments of a colleague as interview object, these a few department about political, economic, cultural, social, environmental protection and so on all aspects of the rural social governance.Secondly, the 26 villages of Y-style town in Conghua District of Guangzhou can be roughly divided into three types of development.East near Hutuo River, the main development of ecological agriculture; Surrounded by botanical gardens in the middle, it is primarily a property development; The western region has just completed the demolition of old heavy industry enterprises and integrated $1500 \mathrm{mu}$ of land, and will soon introduce high-tech projects.Each of the three regions chooses a representative village, and each village chooses a village cadre as the interview object. Finally, in terms of social organizations, Y Style Town in Conghua
District of Guangzhou is a township where the implementation of rural revitalization strategy has just started, with fewer grassroots social organizations and narrow sample selection scope and single type. Specialized farmer cooperatives and private enterprises are selected as representatives for interviews.Through interviews with them, we learn about the implementation of the rural revitalization strategy in the process of rural grass-roots social governance work, existing problems and ideas for improvement and foundation.

\section{Method of induction and summary}

This paper analyzes and summarizes the typical cases of new townsfolk helping rural grassroots governance, and grasps the specific role of new townsfolk in rural grassroots governance and the practical obstacles encountered. Draw on the ideas and viewpoints of scholars in different fields on new townsfolk and rural grass-roots governance, apply them to the research of this project realistically and strive for innovation.

\subsection{Project research technology roadmap}

First of all, by referring to the literature on rural grass-roots social governance under the background of "Internet +", and analyzing the local feelings of new townsfolk and the political foundation related to rural revitalization strategy, the subject of rural grass-roots governance is absent and lacks power, so as to draw out the necessity for new townsfolk to help rural grass-roots governance.

Followed by combining government rural revitalization of the strategic planning of relevant standards, according to the actual situation of guangzhou conghua district $\mathrm{Y}$ town, through the method of questionnaire and interview, the country revitalization under the background of guangzhou conghua district $\mathrm{Y}$ town rural grass-roots social management situation analysis, establishing practice base for the research of paper.With the help of relevant fresh examples, this paper expounds the concrete performance of new townsfolk helping rural grass-roots governance from the four aspects of subject joint force, power support, material basis and value guidance.

Finally, from the three aspects of farmer recognition, external environment and the new township elites themselves, this paper further analyzes the practical obstacles that new township elites help rural grass-roots governance.Finally, in view of the three obstacles in reality, combined with the unique advantages and functions of new townsfolk, explore the path choice of new townsfolk to help rural grassroots governance. 


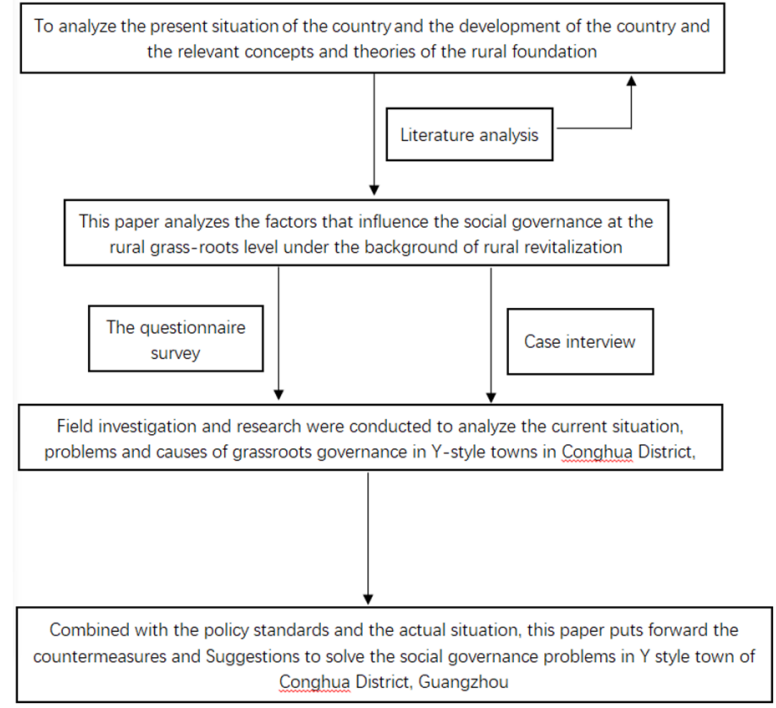

Figure 2 Technical circuit diagram of the project

\section{Key problems solved and innovations}

\subsection{Key issues to be solved}

The difficulties of the research of this project are limited research data. The domestic academic circle has few research results related to "new townsfolk help rural grass-roots governance", and the research content needs to be expanded, and the empirical research on this issue is relatively difficult. The research focus of this project is on the practical obstacles of new townsfolk helping rural grass-roots governance and the path choice of new townsfolk helping rural grass-roots governance.

(1) New townsfolk help provide synergy support in rural grass-roots governance

The new townsfolk can effectively help the rural grass-roots governance in the process of participating in the rural grass-roots governance to provide the main force, integrating and getting close to the farmers to provide the power support, driving the rural economic and social development to provide the material foundation, and disseminating mainstream values to provide value guidance. With the unique localism and moral superiority, new follow villager by participating in the rural grass-roots governance, blend in and near to farmers, drive the rural economic and social development and dissemination of the mainstream values for the rural grass-roots governance main body force, power support, material basis and value guidance, it helps the manifestation of rural grassroots governance is to have eyes and see, for sure.

(2) Promote the practice of democracy and optimize the development of villagers' self-governance organizations

Villagers' committee is the main organization of villagers' self-governance. It is elected by all villagers who have the right to vote and it is the organization to exercise the relevant governance power on behalf of the villagers. Villagers' self-governance organizations, especially villagers' committees, play an important role in social governance at the grass-roots level. However, through the investigation of $\mathrm{Y}$-style town in Conghua District, Guangzhou, it is found that there are still some problems in the development of villager self-governance organization.To solve these problems, the following are the foundations: First, respect the villagers' democratic right to vote and fully mobilize the enthusiasm of villagers' self-governance organizations. We should attach great importance to all aspects of the election of new villagers' committees, elect a village cadre who is in line with the people's will and is responsible for the public interest, and fully mobilize the enthusiasm of villagers for self-governance.Second, we should optimize the construction of villagers' self-governance organizations, and continue to carry out the practice of "the village secretary and the director on one shoulder". Not only the public opinion should be fully respected, but also the leading position of township and village Party committees in villagers' autonomy should be clarified. Township and village Party committees are the strong backing to guarantee the standardized operation of rural work and play a political nuclear role in the work of villagers' autonomy. The leadership direction of the Party is consistent with the development requirements of villagers' autonomy.

(3) Give full play to the strength of multiple entities and improve public credibility.

At present, in the grass-roots social governance of Y-style town in Conghua District, Guangzhou city, the main forces of all parties are lacking to varying degrees. It is necessary to fully explore and give play to the functions and forces of multiple subjects, further optimize the operation mechanism of all parties in the grass-roots social governance, and form a comprehensive force of the grass-roots social governance. Therefore, to give full play to the collaborative governance power of grassroots social organizations, it is necessary to do the following: First of all, it is necessary to increase the intensity of talent training, strengthen the construction of professional team. With the development of science and technology today, the professional requirements for social organizations are also getting higher and higher. Enhance their independence and tap their development potential. It is undeniable that grassroots social organizations are highly dependent on the government. However, in order to achieve long-term development, grassroots social organizations must explore diversified development channels, enhance their independence and autonomy, have the ability to guarantee their benign development and gradually get rid of excessive dependence on the government.The second is to strengthen publicity, the introduction of third-party evaluation institutions, improve credibility.We will improve the credibility of grassroots social organizations and the recognition of rural grassroots social organizations by farmers.Finally, fully affirming the social status and stimulating the enthusiasm of the villagers.Any organization is eager to be recognized by the society, with a sense of belonging, it will be better to 
mobilize the enthusiasm of the township.

\subsection{Innovation}

\section{(1) The perspective is novel}

Rural grassroots governance has always been the focus of academic circles. Although there are numerous related research results, there are also obvious deficiencies. In other words, the perspective of research is mostly from the overall perspective of rural grassroots governance, that is, the research is carried out with the idea of "meaning-current situation-countermeasures".On the basis of in-depth analysis of predecessors' research on social governance issues at the rural grass-roots level, combined with the background of promoting the implementation of rural revitalization strategy, this paper selects y-style towns in Conghua District, Guangzhou for field research.This paper aims at the related problems in rural grass-roots governance, namely, the absence of subjects and lack of motivation. It analyzes the related problems of new townsfolk, as a new group, in helping rural grass-roots governance. The research perspective is relatively new.

\section{(2) Novel content}

In recent years, social governance at the rural grass-roots level has been the focus of scholars from all walks of life. With the continuous development of society, the research on social governance at the rural grass-roots level in China under the new situation needs to be constantly updated. Therefore, the research is conducted from the perspective of implementing the rural revitalization strategy, which meets the needs of social development.The paper along the "why - what - how how to do" train of thought, on the analysis of the new follow villager unique localism and moral advantage, the current subject vacancy of rural grassroots governance and under the premise of underpowered, expounds the new follow villager power of rural grassroots governance, reality, and put forward the corresponding path choice

\section{Summary}

At present, China is in the decisive stage of building a well-off society in an all-round way. Only by resolutely pursuing a path of good governance in rural areas can we better promote effective governance in rural communities, fully implement the rural revitalization strategy, and modernize the country's governance system and governance capacity. The research on rural grass-roots social governance from the perspective of rural revitalization strategy is of certain supplementary meaning to the expansion of grass-roots social governance theory and of certain theoretical value to the promotion of social governance in China at the present stage.

Social governance at the rural grass-roots level is the social foundation for rural revitalization. Without effective social governance at the grass-roots level, the strategy of rural revitalization will not be fully realized.+
Internet governance "is the only way to modernize the grassroots governance, is the basic unit government use of technical means, will be the key to democratic governance and the well-being of the people together, and to guide the new follow villager boost rural grass-roots governance, give full play to the new follow villager power effective positive role in the rural grass-roots governance, both serve the native place of the sense of responsibility and sense of mission, venerable cohesion and the affinity of appeal, reasonable and appealing, make it possible to have new follow villager power rural grassroots governance; It also realized the people-oriented care and embodied the governing policy of the rule of law.

\section{Author}

Zhang Meng, (1984-), female, Han nationality, native of $\mathrm{Lu}$ jiang, Anhui province, Bachelor degree, lecturer. Mainly engaged in ideological and political theory teaching, research fields for ideological and political education, rural governance.

\section{Acknowledgement}

Fund Project This paper is the phased achievement of the Youth Innovation Talents Project of The Education Department of Guangdong Province "New Township Talents Help Rural Moral Construction under the Background of Rural Revitalization" (Project No.: 2019GWQNCX110); Department of science and technology of Guangzhou Nanyang Polytechnic in 2019 (Project No.: ny-2019kyyb-07)

\section{References}

1. Yang zekun. Rural revitalization: a study on the ideal living environment for cultivating "new townsfolk" [J]. Modern business and industry,2020,41(22):22-23.

2. Song Juan. Research on countermeasures for the Introduction and Training of grassroots talents from the perspective of rural revitalization Strategy [J]. Finance and Economics,2020(07):30-31.

3. Journal of northwest a\&f university (social science edition),2020,20(04): 75-81. (in Chinese with English abstract)

4. Yang Xingjun, Organization Department of Muchuan County Party Committee. Juli Rural Governance promotes rural revitalization $[\mathrm{N}]$. Leshan Daily,2020-06-26(003).

5. Sun Yanhui. Research on The Participation of New Townsfolk in Rural Governance under the background of Urbanization [J]. Agricultural Development and Equipment,2020(06):1+3.

6. Quan Juemin, Secretary and Chairman of the CPC Committee of Tongliao. Implementing the rural Revitalization Strategy contributes to promoting the high-quality economic development of Tongliao [N]. 
Tongliao Daily,2020-06-21(003).

7. Ding jing. Research on rural governance from the perspective of rural revitalization [J]. Journal of yanbian party school,2020,36(03):62-66.

8. Guo Xiangyu. Consolidating the achievements of poverty Alleviation and Linking the Strategy of Rural Revitalization [N]. China Social Science Daily,2020-06-17(003).

9. Li Yan. Dilemma and Path of New Villagers participating in Rural Governance under rural Revitalization Strategy [J]. China Collective Economy,2020(17):3-4.

10. Cui Yingyue, Deputy Director of standing Committee of Tongliao People's Congress. Laying a good foundation for the implementation of rural $\begin{array}{lll}\text { revitalization strategy } & {[\mathrm{N}] .} & \text { Tongliao }\end{array}$ Daily,2020-06-14(003).

11. Xiao Lixin. Coordinated Promotion of Poverty Alleviation and Rural Revitalization Strategy [N]. Zhangjiakou Daily,2020-06-13(003).

12. Ge $\mathrm{r}$ g, longhua Lou. On rural spatial governance and urban-rural integrated development [J]. Acta geographica sinica,2020,75(06):1272-1286.

13. Chen Jinhe. Giving play to the advantages of new Townsfolk to Promote rural Revitalization [N]. Yongzhou Daily,2020-06-04(005).

14. li mei, liu shulan, wu junlin. Analysis and countermeasures of new townsfolk participating in the revitalization of rural culture [J]. Journal of yunnan agricultural university (social science),2020,14(03):44-48.

15. Li fangyan. Problems and countermeasures of rural governance in the new era $[\mathrm{J}]$. Journal of yunnan agricultural university (social science),2020,14(03):13-18.

16. Yang Yadong. Research on improving village Affairs Supervision System from the perspective of Rural Revitalization [D]. Hebei Normal University,2020.

17. Li xiuyun, Yang xueying, li yiliang. Discussion on the connotation of new townsfolk in comparative context [J]. Journal of jiangsu ocean university (humanities and social sciences edition), 2020, 18(03): 118-126. 